\title{
Research on dynamic modeling and operation optimization technology of CCHP system in port
}

\author{
Ming $\mathrm{Gu}^{1, \mathrm{a}}$, Wei $\mathrm{Du}^{2, \mathrm{~b}}$ and Teng Tian ${ }^{3, \mathrm{c}}$ \\ ${ }^{1,2,3}$ Number 2618, Xingang road 2, Tanggu district, Tianjin city, China \\ aguminglili@163.com, bwei_du@126.com, ${ }^{c} 196791039 @ q q . c o m$
}

Keywords: distributed combined cooling heating and power, power determined by heat, heat determined by power.

Abstract. Three kinds of optimization evaluation method of distributed combined cooling heating and power (CCHP) system are analyzed, including thermodynamic performance evaluation method, environmental characteristics evaluation method and economic evaluation method. The objective function is determined as the minimum exergy economic coefficient, minimum life cycle cost, maximum net present value and reasonable incremental investment recovery period. The load gross and economic parameter of two kinds of load matching schemes including "power determined by heat" and "heat determined by power" are simulated and analyzed. By comparing the initial investment, natural gas cost, power generating revenue, heating and cooling revenue and recovery period of two different schemes, the "heat determined by power" scheme is more suitable for the port environment and building characteristics.

\section{Introduction}

Many scholars at home and abroad respectively analyze the single factor influence of combined cooling heating and power system economic benefits from cold and hot electricity load level, natural gas price, grid purchase price aspects ${ }^{[1-3]}$.Wang Yanling ${ }^{[4]}$ establishes of the comprehensive value analysis model that suit natural gas distributed energy station, and analysis the value of natural gas distributed energy station from their own, power system, user, and social environment four aspects, quantifies its comprehensive value level, and verify the practicality and effectiveness of comprehensive value model through the numerical example.

In this paper, the economic evaluation model is established, and the objective function of the CCHP is determined. Two kinds of load matching scheme "power determined by heat" and "heat determined by power" of CCHP system are evaluated economically, and the CCHP system solution that suit port area is obtained.

\section{Distributed energy system optimization evaluation method}

\section{Thermodynamic performance evaluation method}

Thermodynamic performance is the core of the evaluation of trigeneration system, and even affects the other technical evaluation index. At present the thermodynamic performance evaluation index of common combined system mainly include energy efficiency, exergy efficiency and reduced power generation rate.

\section{Environmental characteristics evaluation method}

Traditional fuel combustion produces large amount of pollution gases such as carbon dioxide, nitrogen oxides, this will affect the environment to some extent. The evaluation standard is based on the fuel emission factor $\mathrm{CO}_{2}$ and $\mathrm{NO}_{\mathrm{X}}$.

\section{Economic evaluation method}

Net present value method

Net present value (NPV) is the algebraic sum of total present value of the project net cash benefits and net cash investment. The project is considered accepting if NPV is greater than or equal to 0, or unconsidered. 


\section{Investment payback period}

Investment payback period is the required fixed number of year with the project net income to repay the original investment starting from the date of the project of building, including static investment payback period and dynamic payback period. Static payback period don't consider the time value of money, and dynamic payback period consider this. The decision of investment payback period is based on the comparison of project payback period with fixed number of year of the industry benchmark. The project is feasible if the fixed number of year of the payback period is less than the benchmark. The smaller the investment payback period is, the more optimal project economics is.

Full life cycle assessment method

Full life cycle assessment method is a comprehensive method considering the initial investment and operating cost of system ${ }^{[5]}$. The initial investment of air conditioning system equipment and ancillary equipment is equally shared to each year of equipment life cycle, and adding the equipment operation cost every year the operating cost is obtained. In this paper, the minimum life cycle cost (LCC) is selected as objective function, and the optimization evaluation model is set up to optimize the energy system configuration mode and operation strategy. the energy system solution is synthetically considered based on the net present value, exergy economic coefficient and incremental investment payback period. Considering the required equipment price of whole system, allowance for depreciation of equipment, construction period, the bank interest rate is as the lowest yield. Then mathematical model is established, objective function is determined as minimum LCC, maximum net present value, reasonable incremental investment payback period and minimum exergy economic coefficient.

\section{Economic evaluation model}

Distributed energy system is compared with the traditional centralized power energy system, it is directly faced to the user, $r$ various forms of energy are produced and supplied according to the need of use. CCHP is a typical distributed energy system, which combines refrigeration, heating (heating and heating water) and power generation process based on the concept of energy cascade utilization ${ }^{[6-7]}$.

In this paper, objective function is determined as minimum LCC, maximum net present value, reasonable incremental investment payback period and minimum exergy economic coefficient.

\section{Comparison and analysis of distributed energy system scheme in port}

The matching relation between cold, hot and electricity load of distributed energy system is very important. Compared with separate cold, hot and electricity generation system, the superiority of distributed CCHP system is that it realizes the cascade utilization of energy. But it will cause the waste once missing good system configuration, so the choice of configuration principle is also very important. Among the configuration principle of distributed energy system, the main design principles include: design of power station, "power determined by gas", "power determined by heat" and "heat determined by power" ${ }^{,[8]}$. And "power determined by heat" and "heat determined by power" design principles are usually more applicable and reasonable.

The design principle of "power determined by heat" is: giving priority to the user's heat load, the unit capacity is selected on the basis of guaranteeing the user's required cold and hot load, and then considering to choose the appropriate power generating equipment. This principle is to extra supply part of electric load under the premise of ensuring system cold and hot load supply. when the electric load can not meet the requirements the grid is supplemented to use. This principle can be to make full use of waste heat of system, to achieve the goal of improving system energy efficiency.

The design principle of "heat determined by power" is: giving priority to the user's electricity load. When the waste heat of system can not meet user demand for cold and hot load, the supply will use afterburning way. But the change of power load of system itself and required electrical load of user are adjusted through power equipment, and that will makes the system more complicated. For these two design principles, two kinds of schemes are determined for analysis and comparison based on the actual building situation. 


\section{Power determined by heat}

Using the "power determined by heat" design principle, the scheme 1 is proposed: combined cycle unit of gas turbine and direct fired $\mathrm{LiBr}$ absorption chiller of flue gas. Schematic diagram of system is shown in Fig. 1.

\section{Heat determined by power}

Using the "heat determined by power" design principle, the scheme 2 is proposed: combined cycle unit of gas engine and direct fired $\mathrm{LiBr}$ absorption chiller of flue gas. Schematic diagram of system is shown in Fig. 2.

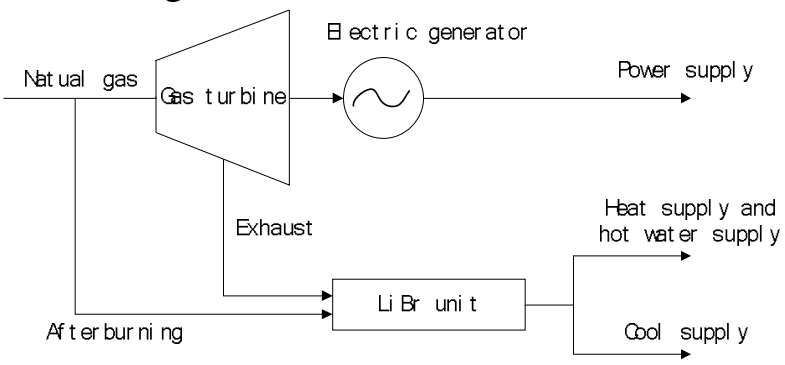

Fig. 1 Schematic diagram of gas turbine and direct fired $\mathrm{LiBr}$ absorption chiller of flue gas

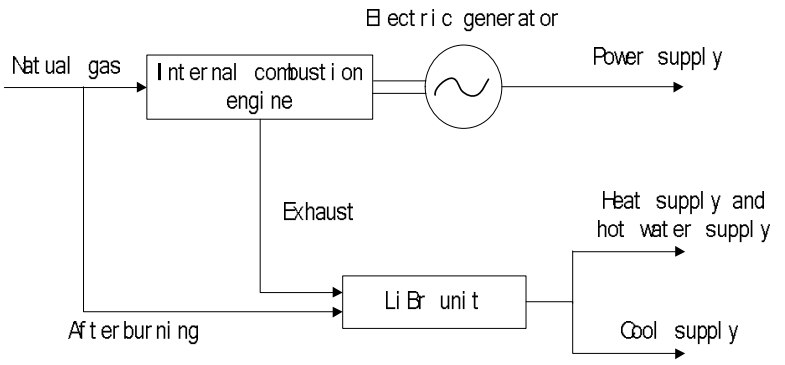

Fig. 2 Schematic diagram of gas internal combustion engine and direct fired $\mathrm{LiBr}$ absorption chiller of flue gas

\section{Scheme comparison}

Total load required

With reference to Tianjin port joint inspection center, the energy supply is obtained when selected equipment operating under standard condition based on above schemes. Compared with the cold, heat, electricity total load required of building, the comparison result are shown in Table 1and Table 2.

Table 1 Energy demand and equipment supply

\begin{tabular}{cccc}
\hline item & demand & scheme 1 & scheme 2 \\
\hline area of structure $\left[\mathrm{m}^{2}\right]$ & 58190 & 58190 & 58190 \\
cooling load $\left[\mathrm{W} / \mathrm{m}^{2}\right]$ & 115 & 100 & 114 \\
total cooling capacity $[\mathrm{kW}]$ & 6692 & 5816 & 6629 \\
heating load $\left[\mathrm{W} / \mathrm{m}^{2}\right]$ & 80 & 62.5 & 88 \\
total heating capacity $[\mathrm{kW}]$ & 4655 & 4660 & 5113 \\
electrical load $\left[\mathrm{W} / \mathrm{m}^{2}\right]$ & 101 & 35 & 101 \\
total electrical capacity $[\mathrm{kW}]$ & 5882 & 4080 & 5890 \\
\hline
\end{tabular}

Table 2 Comparison of scheme and demand

\begin{tabular}{ccc}
\hline item & comparison with scheme 1 & comparison with scheme 2 \\
\hline total cooling capacity difference $[\mathrm{kW}]$ & -876 & -63 \\
total heating capacity difference $[\mathrm{kW}]$ & 5 & 458 \\
total electrical capacity difference $[\mathrm{kW}]$ & -1802 & 8 \\
\hline
\end{tabular}

It can be seen from the table above, in scheme 1, the heating capacity and capacity required of building keep consistent basically, the cooling capacity is short of $876 \mathrm{~kW}$, and the total electrical capacity is short of $3842 \mathrm{~kW}$; in scheme 2 , the cooling capacity is short of $63 \mathrm{~kW}$, the heating capacity has $458 \mathrm{~kW}$ margin, and the electrical capacity has $8 \mathrm{~kW}$ margin. For the factor of electricity shortage of above two schemes, it can be solved through using grid power supply. For the problem of shortage of heating capacity and cooling capacity, it can be solved through using afterburning way of direct fired machine of flue gas. The excess cooling capacity can be ready for the peak through storing cool storage device

According to internal demand and the law of the building itself, and different operation time of equipment, the two different schemes use the same running time law. In the heating period in winter, cooling period in summer, non-heating period and non-cooling period in spring and autumn, the unit runs at full capacity. The unit peak regulation problem of heat supply and cool supply will be solved through using afterburning way of direct fired machine of flue gas. 
Economic contrast analysis

The initial investments of distributed energy system mainly include the cost of electric power equipment, direct fired $\mathrm{LiBr}$ absorption chiller of flue gas, heat recovery unit, installation of worker, ancillary facilities, tariff (including import tariff and value-added tax) and so on. Because the electric power equipment selected for scheme need to be imported from abroad, so the import tax calculates according to $30 \%$. The initial investments of different schemes is shown in Table 3 . And the revenue of power generating, heat supply and cool supply are shown in Table 4 and Table 5.

Table 3 Initial investments of different schemes

\begin{tabular}{ccc}
\hline item & scheme 1 & scheme 2 \\
\hline cost of electric power equipment [¥/y] & 10060000 & 12890000 \\
tariff [¥/y] & 3020000 & 3870000 \\
direct fired LiBr absorption chiller of flue gas [¥/y] & 8500000 & 24800000 \\
transport and installation charge [¥/y] & 2000000 & 5700000 \\
total investment [¥/y] & 23580000 & 47260000 \\
\hline
\end{tabular}

Table 4 Power generating revenue

\begin{tabular}{ccc}
\hline item & scheme 1 & scheme 2 \\
\hline annual power generating capacity $[\mathrm{kW} \cdot \mathrm{h} / \mathrm{y}]$ & 14892000 & 15646120 \\
annual power purchase capacity $[\mathrm{kW} \cdot \mathrm{h} / \mathrm{y}]$ & 6577300 & 0 \\
net annual revenue of electricity $[\mathrm{kW} \cdot \mathrm{h} / \mathrm{y}]$ & 8314700 & 15646120 \\
electricity price $[¥ / \mathrm{kW} \cdot \mathrm{h}]$ & 1.05 & 1.05 \\
annual revenue of power purchase $[¥ / \mathrm{y}]$ & 8730435 & 16428426 \\
\hline
\end{tabular}

\begin{tabular}{ccc}
\hline \multicolumn{2}{c}{ Table 5 Heat supply and cool supply revenue } & \\
\hline item & scheme 1 & scheme 2 \\
\hline annual cool supply [kW/y] & 21228400 & 24195850 \\
cool capacity price [¥/kW] & 0.292 & 0.292 \\
annual total revenue of cool supply [¥/y] & 6198693 & 7065188 \\
annual heat supply [kW/y] & 17009000 & 16990750 \\
heat capacity price [¥/kW] & 0.125 & 0.125 \\
annual total revenue of heat supply [¥/y] & 2126125 & 2123844 \\
total investment [¥/y] & 8324818 & 9189032 \\
\hline
\end{tabular}

After distributed energy system putting into use, the main operation cost include gas fuel expenditure and system operation maintenance.

It can be known from the analysis of scheme configuration, the gas turbine and gas internal combustion engine both consume natural gas when operation. In scheme 1, the cool supply and heat supply can meet the demand, so afterburning is needless. But in scheme 2, the cool supply and heat supply can not meet the demand, the afterburning of direct fired $\mathrm{LiBr}$ absorption chiller of flue gas need to consume natural gas. The calculation of natural gas consumption and cost expense are shown in Table 6 and Table 7.

Table 6 Natural gas consumption and cost expense

\begin{tabular}{|c|c|c|c|}
\hline item & season & scheme 1 & scheme 2 \\
\hline \multirow{3}{*}{$\begin{array}{l}\text { natural gas consumption of power } \\
\text { generating }\left[\mathrm{m}^{3}\right]\end{array}$} & spring, autumn & 1216340 & 1333460 \\
\hline & summer & 1226310 & 1344390 \\
\hline & winter & 1196400 & 1311600 \\
\hline \multirow{5}{*}{$\begin{array}{l}\text { natural gas consumption of direct } \\
\text { fired machine of flue gas }\left[\mathrm{m}^{3}\right]\end{array}$} & all year & 3639050 & 3989450 \\
\hline & spring, autumn & 0 & 0 \\
\hline & summer & 1077480 & 77490 \\
\hline & winter & 0 & 0 \\
\hline & all year & 1077480 & 77490 \\
\hline natural gas price $\left[¥ / \mathrm{m}^{3}\right]$ & all year & 3 & 3 \\
\hline annual natural gas cost $[¥ / y]$ & all year & 14149590 & 12200820 \\
\hline
\end{tabular}


Table 7 Comprehensive comparison of different schemes

\begin{tabular}{ccc}
\hline item & scheme 1 & scheme 2 \\
\hline initial investment [¥] & 23580000 & 47260000 \\
natural gas cost [¥] & 14149590 & 12200820 \\
power generating income [¥] & 8730435 & 15646120 \\
heat and cool supply income [¥] & 8324818 & 9189032 \\
payback period [y] & 8 & 4 \\
\hline
\end{tabular}

\section{Conclusions}

Through analysis, the initial investment of scheme 2 is higher, but the various economic indicators are more superior to that of scheme 1.After comprehensive consideration the scheme 2 is more suitable for the port environment and building characteristic.

\section{References}

[1] Aiguo Liu: Beijing: Institute of Engineering Thermophysics, Chinese Academy of Sciences, 2009.(In Chinese)

[2] LI C Z, SHI Y M, HUANG X H: Energy Conversion and Management, 2008, 49(12): 3491-3497

[3] Zhibing Feng, Hongguang Jin: Journal of Engineering for Thermal Energy and Power, 2005, 20(4): 425-429. (In Chinese)

[4] Yanlin Wang, Bei Li, Hang Cui: Automation of Electric Power Systems, 2016, 40(1): 136-142. (In Chinese).

[5] Wei Li, Zhimin Zhu, Jinzhong Zhu: Journal of Electric Power, 2011, 26(6):487-498. (In Chinese).

[6] Rumei Lin, Hongguang Jin, Ruixian Cai: Power Engineering, 2003, 23(3): 2370-2376. (In Chinese)

[7] Gianfranco Chicco, Pierluigi Mancarella: Renewable and Sustainable Energy Reviews, 2007, 13: 535-551.

[8] Yuhong Li: Distributed energy electricity thesis symposium proceedings, Shanghai, 2003, 6-9. (In Chinese) 